\title{
The central role of IT capability to improve firm performance through lean production and supply chain practices in the COVID-19 era
}

\author{
Hotlan Siagian $^{a}$ and Zeplin Jiwa Husada Tarigan ${ }^{a^{*}}$
}

${ }^{a}$ Master Management Program, Petra Christian University, Jl. Siwalankerto, Surabaya, Indonesia

\begin{tabular}{l}
\hline C H R O N I C L E \\
\hline Article history: \\
Received April 6, 2021 \\
Received in revised format May \\
16,2021 \\
Accepted June 102021 \\
Available online \\
June 182021 \\
\hline Keywords: \\
Information technology capability \\
Lean production \\
Vendor-managed inventory \\
Supply chain practices \\
Firm performance
\end{tabular}
\begin{abstract}
A B S T R A C T
Today, global competition entails companies having an advantage in supply chain networks to pursue superior performance. This work examines the link between information technology (IT) capability with the firm performance by adopting a lean production approach, vendor-managed inventory, and supply chain practices. The study has surveyed the population of the manufacturing company in East Java, Indonesia, using a questionnaire with a five-point Likert scale. A total of 111 manufacturing companies (medium and large) were selected from 5420 manufacturing companies listed in the Industrial Department of East Java. The partial least square (PLS) technique was used to analyze the data, using the SmartPLS software version 3.3. Thirteen hypotheses in this study were developed to investigate. The result revealed that all hypotheses of direct relationship were supported. IT capability directly affects lean production, vendor managed inventory, and supply chain practices. Moreover, lean production, vendormanaged inventory, and supply chain practices improve firm performance. Further analysis also indicated that all hypotheses of indirect hypotheses were supported except hypothesis one hypothesis (H9). IT capability indirectly improves firm performance through lean production, vendor-managed inventory, and supply chain practices. The result provides insight for managers and policymakers on enhancing firm performance by improving its IT capability, adopting lean production, vendor-managed inventory, and supply chain practices. This research contributes to reinforcing the supply chain management theory.
\end{abstract}

(C) 2021 Growing Science Ltd. All rights reserved.

\section{Introduction}

The Covid-9 pandemic has altered people's lives in every way, especially in health and economics worldwide. It has disrupted supply and demand with very high uncertainty. The impact of the covid-19 has exposed many manufacturing companies to having difficulty procuring raw materials and marketing the products they produce (De Sousa Jabbour et al., 2020). The products required by the community in handling the disease caused by the virus have experienced stock out, and it is tough for customers to get them. Moreover, Covid 19 has resulted in changes in the manufacturing system by adopting system automation using information technology, particularly making the right decisions for decision-makers (Sarkis, 2021). The information technology used encourages the manufacturing companies to recover to previous conditions quickly or close to normal conditions before the Covid disruption occurred. This increment demonstrates that manufacturing firms have regained their operating performance following the Covid-19 pandemic. However, it is unclear what the organization has done to improve its results. As the COVID-19 pandemic has not indicated any decline in its spreading worldwide, the instability of demand and supply remains. In the business world, instability increases the risk of being unable to adapt to changing demands. The instability could result in various consequences such as excess or shortage of stock, resulting in significant losses because they will have to pay off the unsold inventory and shortage stock. In addition, the Government of Indonesia has imposed a

* Corresponding author

E-mail address: zeplin@petra.ac.id (Z. J. H. Tarigan)

(C) 2021 Growing Science Ltd. All rights reserved.

doi: $10.5267 /$ j.uscm.2021.6.012 
new normal way of life by implementing the healthy protocol activities, namely, using masker, social distancing, and avoiding any crowded event. The crucial question is what strategy and policy the organization should employ to continue operating and conducting business when coping with the uncertainty in demand and supply during the Covid-19 pandemic. The main answer to the question is that the organization should implement an ambidextrous strategy to deal with any supply and demand disruption created by the pandemic. Every business must develop a strategy to respond quickly and flexibly to changing supply and demand trends. Manufacturing companies must implement a production system that can adapt to changing demand rapidly, such as lean production practices. However, lean production could not stand alone in practice, but it should collaborate upstream like vendor-managed inventory and downstream in supply chain practices, particularly with distributors and retailers. Moreover, the company should adhere to the policy, a new normal way of life, imposed by the Government to prevent the worsening spread of the current pandemic. Thus, one solution for this situation is to enhance its information technology (IT) capability to collaborate with internal and external partners, enabling lean production and supply chain practices to pursue superior firm performance (Siagian et al., 2020; Khalil et al., 2019). Enterprise supply chains must be robust and sustainable to enable effective responsiveness, eliminate vulnerabilities, and minimize the impact of unfavorable disruptions.

Many research studies have dealt with production management principles and demonstrated how to boost company performance during the dynamic market condition (Suryanto \& Mukhsin, 2020). Lean production is a production system philosophy that focuses on reducing waste and inventory to increase agility. According to Hardcopf et al. (2021), Lean production will boost a company's firm performance. According to Tarigan (2018), firm performance is determined by how a business achieves cost, quality, and delivery. By reducing non-value-added activities, lean production improves each member's competitive advantage in the supply chain, resulting in lower costs, faster response, and higher product quality. The implementation of lean production should focus on the understanding that proper sustainable performance comes from the financial benefits extracted from reduced inventory costs that can be accomplished with a refined storage system to provide a robust mechanism to adapt to market changes quickly (Hao et al., 2021).

Other studies have shown that manufacturing companies can improve their firm performance by implementing a vendormanaged inventory (VMI) framework. VMI is a form of partnership between manufacturers and their suppliers. Suppliers are an integral part of the manufacturing company's supply chain in this concept, and they control their stock to support manufacturing needs. VMI could resolve the complexities and disruption of the supply of raw materials and components, especially in the inventory system (Mateen \& Chatterjee, 2015). Introducing VMI, a continuous replenishment partnership operated by external parties, such as suppliers, management can overcome the issue of demand fluctuation. Companies, therefore, need suppliers domiciled in a specific geographic region to reduce the risk of a problem area since each local Government's policies are different in reacting to this pandemic situation. The existing supply chain should adapt to the current market in anticipation of uncertainties due to rapid changes and high volatility due to evolving lifestyles like the new normal lifestyle. As a result, businesses must build and use their primary resources to boost competitive strengths such as low cost and high quality and adopt supply chain practices to deter rivals from duplicating their efforts (Tarigan et al., 2021b). Collaborative supply chain relationships are a significant strategic factor in assisting businesses in achieving mutually compatible and competitive objectives (Tarigan et al., 2019).

Lean production arose from the direct application of firm principles to the industry and has since grown to include supply chains in many companies (Chen et al., 2013). The company's external partners must support lean production. Collaboration with third parties other than manufacturers must be well-established by incorporating supply chain best practices, also known as supply chain practices (Khalil et al., 2019; Tarigan et al., 2021a; De Sousa Jabbour). Companies are encouraged to maximize shorter time and lower costs because of market competition. Lean production must be extended to include external stakeholders to define and eliminate waste in internal and external processes (Hao et al., 2021). Guimarães et al. (2013) looked into the logistics officer, operating personnel, hospital CEO, Pharmacy director, and chief nurses in the health sector. The findings indicate that lean supply chain and vendor-managed inventory have a good relationship, with lean supply chain encouraging companies to partner with suppliers via VMI (Cai et al., 2017). Lean production in manufacturing companies with six dimensions defined by process control \& improvements, just-in-time flow, workforce development, maintenance management, customer focus, and supplier relationships can improve business performance (Abreu-Ledón et al., 2018).

All the above conceptual constructs require a supporting tool enabling all parties to communicate and collaborate. Research by Liu et al. (2015) suggests that using information technology by developing their software and hardware can improve company performance during a dynamic market demand. Companies need information technology (IT) capabilities in exchanging information between internal and external parties to improve the company's firm performance (Al-Shboul et al., 2017). Given the current pandemic, IT has become one of the best options for the manufacturing company. Companies need the IT capability to help during this pandemic in communicating, integrating, and coordinating all related companies ranging from suppliers, manufacturers, distributors, retailers to customers. The role of IT capability in the supply chain is crucial in improving company performance. In their research, Omar et al. (2010) said that companies with robust IT capabilities could improve the company's supply chain processes, such as improving delivery times, reducing costs, and making companies more responsive. IT capability in integrating the supply chain partners can improve its firm performance. IT allows the 
company partners to increase the information exchange during this pandemic where its activities are severely restricted. Companies need to improve their IT capabilities both in terms of software and hardware. In several studies, it was noticed that IT capability is the key to a company's success in implementing supply chains (Flynn et al., 2010). These studies say that companies and corporate partners need to be equipped with reliable IT capabilities to produce maximum collaboration. IT capabilities enable the companies to organize, integrate, and use resources to meet business needs. IT capability enables the implementation of vendor-managed inventory since it requires real-time information sharing between the company and its supplier (Marinagi et al., 2014). A vendor-managed inventory concept focused on the supplier's continuous replenishment of raw material or components to support the manufacturing firm activities. Hence, the company should have a robust IT capability. Besides supporting the vendor-managed inventory, IT capability also plays an essential role in implementing supply chain practices. IT capability highly supports the supply chain practices success and subsequently improves the firm performance (Siagian et al., 2020). Marinagi et al. (2014) have surveyed 76 manufacturing firms in Greece and confirmed that information technology supported the adoption of supply chain integration. Business performance in manufacturing companies is obtained by achieving internal operation performance and external operation performance supported by information management as IT capability (Prajogo, 2018).

Based on previous studies, it appears that incorporating lean production, vendor-managed inventory, and supply chain practices will increase firm performance in the context of supply chain management. On the other hand, the previous study indicates that the researchers are only interested in the direct impact of these variables on firm performance. This research develops a model that examines the multiple relationships between those four variables in a single model to investigate the effect of IT capability on firm performance through lean production, vendor-managed inventory, and supply chain practices as the mediating variable. The novelty of this research is the creation of a model for improving firm performance by implementing lean production, vendor-managed inventory, and supply chain practices simultaneously. Furthermore, this study was carried out amid the Covid-19 pandemic in East Java, Indonesia. This study may also help business executives improve organizational performance in the sense of supply chain management. This research may also enrich and reinforce the current supply chain management theory. This research model raised three main groups of questions to investigate as follows: First, does IT capability directly influence lean production, vendor-managed inventory, and supply chain practices. Second, do lean production, vendor-managed inventory, and supply chain practices directly affect firm performance. Third, does IT capability indirectly affect firm performance through the mediating role of lean production, vendor-managed inventory, and supply chain practices.

The following is how the rest of the paper is structured. The Literature review of IT capability, lean production, vendormanaged inventory, supply chain practices, and firm performance are discussed in Section 2. It also proposes the study hypotheses to investigate. Section 3 dealt with the methods of scientific analysis and the metrics used. Analysis results and findings are presented in Section 4. The consequences of findings are discussed in section 5. Finally, Section 6 summarizes the study conclusion, limitation, and suggested future research topics based on the findings.

\section{Literature review}

\subsection{Supply Chain Management}

The supply chain encompasses all activities and processes involved in transferring products and information from the raw material stage to the stage at which customers receive them. Supply chain management refers to coordinating activities and processes by supply chain participants (Khalil et al., 2019; Tarigan et al., 2021b). Supply chain management is the process of coordinating the movement of information, goods, and services through a network of consumers, businesses, and supply chain partners (Tarigan et al., 2019). Supply chain management is also characterized as a collection of methods used to efficiently integrate suppliers, distributors, warehouses, and stores so that the product generated can be delivered in the appropriate quantity, to the appropriate location, and at the appropriate time to reduce costs and meet customer expectations.

\subsection{IT capability}

Information Technology is related to software/ programs, networking, hardware, and individuals who work in information technology (Tarigan et al., 2021a). Companies need information technology to return to their initial position by using the internet of things (IoT) and cloud computing and cognitive computing with its supply chain to facilitate decision making (Sarkis, 2021). IT capability, which is a rare, valuable, replicable, and irreplaceable resource, can help companies gain a competitive advantage. IT capability enables the company to share information and build long-term collaborative relationships in the supply chain network (Zhang et al., 2016). Companies that adopt modern IT for their business operations can retrieve massive information from internal or external sources to sophisticated internal and external partners (Prajogo, 2018). IT capability is not just a supportive system for a company, but it should become a core competence to stay in business. According to Kamjdoug et al. (2019), IT capability is divided into three parts: IT Management, IT Infrastructure, and IT personnel. IT capability reflects its ability to provide reliable, consistent, and up-to-date information technology capabilities to support current business operations (Liu et al., 2015). This works measures the IT capability adopting the study of Liu et al. (2015), which uses four indicators, namely, the extent to which company IT capability support the business processes (AC1), information systems are integrated to enable rapid change (AC2), information systems are compatible with company requirement (AC3), and information system is highly reliable (AC4). 


\subsection{Lean Production}

Lean production is defined as a system that eliminates waste (such as raw material requirements) in response to customer demand to improve efficiency and effectiveness (Hao et al., 2021). Jabbour et al. (2013) used indicators in research conducted in the Brazilian automotive industry: multifunctional involvement in the process, continuous improvement, 5S, total productive maintenance, kanban, JIT (just in time) stochastic manufacturing. Dora et al. (2013) define lean manufacturing as the process of finding, removing, and minimizing activities that do not add value to the supply chain process by the use of the appropriate tools and techniques, whereas Dora et al. (2013) use engagement as the metric for evaluating lean manufacturing in the food industry. Of top management, tradition, compartmentalization, coordination, the process's essence, and the nature of the product. Lean production as a company activity in production to reduce non-value-added needs to be implemented continuously. Control \& Improvements, Just-in-time flow, workforce development, maintenance management, customer focus, and supplier relationships (Abreu-Ledón et al., 2018).

Manzouri et al. (2014) describe lean production as a systematic approach to identifying and eliminating non-value-added or wasteful practices through a continuous improvement process. In the manufacturing sector, the metrics used to quantify lean production are productivity, performance enhancement, customer service improvement, manufacturing cost reduction, waste reduction, and profitability. The idea used in this study is that suggested by Manzouri et al. (2014), which shares several parallels with some of the concepts discussed previously, that lean production is a systematic approach to identifying and eliminating non-value-added or wasteful practices through a continuous improvement process (Chen et al., 2013). Among the numerous indicators used in previous research, the useful indicators in this study's sample were those used indicators to quantify lean production in the manufacturing industry: multifunctional participation in the process (LM1), continuous improvement (LM2), implementation of 5S (LM3), total productive maintenance (LM4), adoption of kanban systems (LM5), adoption of just in time management (JIT) (LM6), stock reduction (LM7), and kaizen circles implementation (LM8).

\subsection{Vendor-Managed Inventory}

Vendors-managed inventory, also known as continuous replenishment or supplier-managed inventory, is one of the most widely used collaborations and information-sharing initiatives among trading partners (Cai et al., 2017). Vendor-managed inventory is a supply chain initiative in which the vendor determines the appropriate inventory level and policy for each product (Mateen and Chatterjee, 2015). Vendor management inventory is a strategy used by companies to reduce inventory levels along with the supply chain flow, thereby reducing fluctuations in upstream demand caused by the bullwhip effect (Escuín et al., 2017). The standard framework of the VMI agreement serves as the foundation for the partnership with vendors regarding continuous filling decisions. Binding laws also govern VMI agreements between manufacturing and vendor contracts (Sainathan and Groenevelt, 2019). The process starts by understanding and agreeing to all terms to understand what is required from the partnership (Tarigan and Siagian, 2021; Escuín et al., 2017). Vendor-managed inventory is a method of maximizing supply chain performance. Vendors have access to customer inventory data and are responsible for maintaining the amount of inventory expected by customers' demand (Cai et al., 2017). This partnership promotes collaboration and knowledge sharing among supply chain participants (Tarigan et al., 2019), continuously monitored to ensure that performance continues to improve. Vendor Controlled Inventory as a sustainable filling managed by suppliers, a partnership initiative capable of promoting cooperation and knowledge sharing among trading partners (Cai et al., 2017). Claassen et al. (2008) discovered that the performance of manufacturing firms that adopt systems affects the quality of information, the quality of buyer-supplier relationships, and the level of information exchange between buyers and suppliers. Multiple metrics are used to evaluate vendor-managed inventory, including information quality, information exchange, partnership quality, perceived industrial vending system performance, cost benefits, service benefits, and inventory benefits. Vendor-managed inventory is a sustainable filling method that can foster collaboration and knowledge sharing among partners (Cai et al., 2017). Commerce. From a variety of indicators used in previous studies, the indicators used in this analysis are suggested by Claassen et al. (2008), who propose seven indicators to quantify vendor-managed inventory. The study sample is concerned with the mutual agreement with supplier VMI1), collaborative forecasting (VMI2), the establishment of quality relationship (VMI3), agreed vendor performance measurement (VMI4), cost benefits for both partners (VMI5), service benefits from the vendor (VMI6), and inventory benefits (VMI7).

\subsection{Supply Chain Practices}

Supply chain practices have been described as a structured method for assessing the effectiveness and performance of supply chains (Anand \& Grover, 2015; Tarigan et al., 2021a; Al-Shboul et al., 2017). In some automobile industries, measuring supply chain practices promotes mutual integration among supply chain participants (Suryanto and Mukhsin, 2020; Khalil et al., 2019). Measuring supply chain activities is critical to ensuring that the supply chain process is continuously improved (Tarigan et al., 2019). According to Blome et al. (2014), supply chain practices refer to a company's potential ability to establish alliances with strategic suppliers, develop customer relationships, and exchange knowledge, vision, priorities, and risks. Through conceptualizing the seven key concepts, not only for the company's internal operations but also for the company's suppliers and primary customers, Blome et al. (2014) can quantify supply chain practices in the manufacturing industry in Europe, specifically supply-side sustainability collaboration, demand management, and demand management. Li et al. (2016) describes supply chain practices as a set of activities undertaken by an enterprise to maintain an efficient supply chain. Supply chain activities in the manufacturing sector, specifically strategic supplier partnerships (SSP), information sharing levels, information sharing performance, and postponement (Tarigan \& Siagian, 2021; Li et al., 2016). Anand and 
Grover (2015) suggested the theory used in this study, which shares several parallels with some of the concepts discussed previously, namely that supply chain practices are a structured method for assessing the efficacy and performance of supply chain operations. The indicators used in this analysis are those suggested by Li et al. (2016), who suggest five indicators to quantify Supply chain practices: strategic supplier partnership (SCP1), customer relationship management (SCP2), information sharing between partners (SCP3), quality information sharing (SCP4), and postponement of differentiation (SCP5).

\subsection{Firm Performance}

Firm success refers to the performance with which a business operates, which can help understand its competitiveness and profitability in the market (Tarigan, 2018; Suryanto \& Mukhsin, 2020). Manufacturing business performance is measured by two dimensions, namely market share performance and financial performance (Al-Shboul et al., 2017; Abreu-Ledón et al., 2018). Market share performance is determined by the indicator items of market share, growth of market share, growth of sales. For financial performance, return on investment, growth in return on investment, the profit margin on sales, and overall competitive position are determined (Al-Shboul et al., 2017). Internal firm performance is the achievement of manufacturing companies in a certain period which can also be measured by production efficiency, inventory turnover, and productivity/asset utilization (Projogo et al., 2018; Vanichchincai, 2019).

Firm success is a mindset shift in a business that begins with a competitive advantage and progresses to strategic organizational capabilities (Siagian et al., 2020). These steps, which include consistency, expense, distribution, and flexibility, may be measured on a short-term basis (Bhaird et al., 2011). Firm performance is a broad term that encompasses financial and business performance (Tarigan \& Siagian, 2021). Firm performance is a composite measure of a business's performance, including product production performance, quality fulfilling, customer satisfaction, delivery time and flexibility (Tarigan et al., 2021b). Besides, there are minimal wait times. The measurement indicators for firm performance are reduced cost (OP1), increased productivity (OP2), increased new product development (OP3), process flexibility practices (OP4), and responsive delivery (OP5) because they are pertinent for evaluating research samples in the manufacturing industry.

\subsection{Conceptual Relationship}

\subsubsection{IT capability, Lean production, and Firm performance}

As discussed previously, lean production is a conceptual approach dealing with the production process, with the primary objectives of eliminating waste and non-value-added activities (Manzouri et al., 2014; Chen et al., 2013). Lean production implementation requires cross-functional cooperation in terms of information and communication and external collaboration (Hao et al., 2021). Therefore, the lean production process requires support using information technology, enabling all involved parties to work together in real-time. Research by Moyano-Fuentes et al. (2012) revealed that information technology supported the implementation of lean production. This argument concludes that IT capability has an impact on lean production. The company's IT capability consisting of information and communication technology (ICT) affects company performance by integrating the company's IT system (Zhang et al., 2016). IT Capability also influences firm performance with the mediation of an information security management system (Kamjdoug et al., 2019). Furthermore, there is a correlation between lean production and firm performance (Hardcopf et al., 2021). Lean production has an impact on increasing business performance, namely financial performance, and market performance (Abreu-Ledón et al., 2018)

Based on the above explanation, the first hypothesis can be stated as follows:

$\mathbf{H}_{1}$ : IT capability affects lean production.

$\mathbf{H}_{2}$ : Lean production has a significant impact on firm performance.

$\mathbf{H}_{3}$ : IT capability indirectly impacts firm performance through lean production.

\subsubsection{IT capability, Vendor-managed inventory, and Firm performance}

Research by Marinagi et al. (2014) and Dasaklis \& Casino (2019) found that information technology supports the implementation of vendor-managed inventory. This research suggested that IT capability supports vendor-managed inventory implementation. Meanwhile, inventory managed by vendors enables the company to improve its competitive strategy and firm performance (Tarigan \& Siagian, 2021). This approach should be focused on the consumer and incorporate value-added processes involving consumers, vendors, new product creation, and order fulfillment. By concentrating on these partnerships, the business will meet consumer expectations and gain a competitive edge over its rivals. Companies may operate a vendormanaged inventory system where vendors handle customer inventory and replenish products when stocks run low (Cai et al., 2017). Inventory managed by vendors can help businesses develop and streamline their core order fulfillment processes, saving time and money and which allows them to concentrate on quality improvement and customer support (Cai \& Yang, 2014). The vendor-managed inventory (VMI) achieved performance improvements in various supply chain scenarios characterized by market volatility and waiting time, both of which were thoroughly discussed (Escuín et al., 2017). The study's findings suggest a significant decline in VMI's output increase due to increased consumer demand uncertainty. The second finding indicates that as the external supplier's production capacity decreases, so do the profits generated by VMI. These results imply that the VMI program's performance is contingent on the program's internal dynamics and external influences. 
The third result demonstrates that VMI impacts lead time, where VMI offers a degree of performance enhancement while maintaining a constant lead time ratio. Based on the above description, the following hypotheses are proposed.

$\mathbf{H}_{4}$ : IT capability directly affects vendor-managed inventory.

H5: Vendor-managed inventory directly affects firm performance.

H6: IT capability indirectly affects firm performance through vendor-managed inventory.

\subsubsection{IT capability, Supply chain practices, and Firm performance}

Marinagi et al. (2014) have surveyed 76 manufacturing firms in Greece and confirmed that information technology supported the adoption of supply chain integration. On the other hand, supply chain practices enhanced firm performance. Supply chain practices significantly impact their operating performance and ability to achieve a competitive edge in chain production (AlShboul et al., 2017). Abdallah et al. (2016) researched manufacturing firms in Turkey to determine the impact of supply chain activities on firm performance and how the business can enhance employee performance to achieve better firm performance. Based on the above description, the following hypotheses are proposed

$\mathbf{H}_{7}$ : IT capability directly influences supply chain practices.

H8: Supply chain practices have a direct impact on firm performance.

H9: IT capability has an indirect effect on firm performance through supply chain practices.

\subsubsection{IT capability, Lean production, Vendor-managed inventory, and Firm performance}

Increased knowledge exchange about consumer demand and supplier delivery enables businesses to improve their manufacturing and delivery processes. Guimarães et al. (2013) discovered a strong correlation between lean supply chain and the health industry's logistics executives, operating staff, hospital CEOs, pharmacy directors, and chief nurses. Vendormanaged inventory supports lean manufacturing. Collaboration with VMI suppliers is important to eliminate practices that add little value to the hospital care process, minimize hospital supply chain costs, and improve hospitals' capacity to resolve supply chain obstacles. This argument, together with previous hypotheses H1 and H4, the following hypotheses are determined. Vendor-managed inventory can be used by companies as a form of service that can manage inventory levels for sensitive customers and is also able to maintain inventory levels throughout the supply chain flow to increase mutual competitiveness for members (Cai et al., 2017). Vendor-managed inventory can be used by companies with vendors in revenue sharing to achieve an excellence performance in the supply chain (Sainathan \& Groenevelt, 2019). Based on the above argument, the following $\mathrm{H} 10$, and $\mathrm{H} 11$ are postulated.

$\mathbf{H}_{\mathbf{1 0}}$ : Lean production has a direct impact on vendor-managed inventory.

$\mathbf{H}_{11}$ : IT capability indirectly affects firm performance through lean production and vendor-managed inventory.

\subsubsection{IT capability, Lean production, Supply chain practices, and Firm performance.}

The link between lean production and supply chain management emerged from applying firm techniques directly to the supply chains of several companies with inefficient transportation, storage and retrieval operations (Chen et al., 2013). Due to increased market competitiveness, lean production should be extended to include external stakeholders to recognize and eliminate waste in internal and external processes. As a result, (Hardcopf et al., 2021) recommend that a lean production system eliminates waste by minimizing internal and external variability in the supply chain. Lean production requires a paradigm change away from short-term benefit, the ability to bargain with trading partners, and reliance on trading partners toward long-term relationships with supply chain participants actively attempting to eliminate waste non-value-added activities along the supply chain. Supply chain practice is defined as an integration between internal and external functions as a form of IT capability. A study conducted in 249 Jordanian manufacturing firms revealed that supply chain integration improves firm performance and supply chain performance (Al-Shboul et al., 2017). Vanichchincai's (2019) research on Thailand's manufacturing industry demonstrates that lean manufacturing practices have a significant impact on supply chain relationships and supply chain performance. Lean production refers to more efficient communication and transactions between suppliers and customers through more efficient raw material delivery from suppliers. Based on the preceding explanation, the following $\mathrm{H}_{12}$, and $\mathrm{H}_{13}$ hypothesis can be stated as follows:

$\mathbf{H}_{12}$ : Lean production affects supply chain practices.

H13: IT capability affects firm performance through lean production and supply chain practices.

The $\mathrm{H}_{13}$ hypothesis is determined based on previous direct hypotheses, namely, hypotheses $\mathrm{H}_{1}$ and $\mathrm{H}_{8}$.

\section{Research method}

This study employed explanatory quantitative analysis methods. Quantitative research makes use of numerical data and statistical analysis. This study's population consisted of manufacturing firms based in East Java. East Java has 5024 manufacturing firms, according to data collected from the East Java Central Statistics Agency. After calculating the sample size using the formula, it is determined that the minimum number of samples needed for this analysis is 67 . The questionnaire 
for this analysis employs a Likert scale of 1-5. The first state strongly disagrees, while the fifth state strongly agrees. The respondents were at the management level with a minimum position as supervisors in charge of production, purchasing, logistics, information technology, warehousing, and quality control. The manufacturingindonesia.com website obtains company information such as phone number, email address, mail address, and WhatsApp. The questionnaire was sent to 250 respondents, including an introductory cover letter, in June 2020. The questionnaire was created in the google form, and the distribution was conducted through email and social media. A total of 125 questionnaires were received, and the response rate was 50\%. However, only 111 could be processed because some respondents did not meet the survey requirements due to their lack of a minimum supervisory role. Partial least squares (PLS) was utilized to analyze the data using SmartPLS software version 3.0 (Hair et al., 2019). PLS is a robust technique to analyze the data of less than 200 respondents.

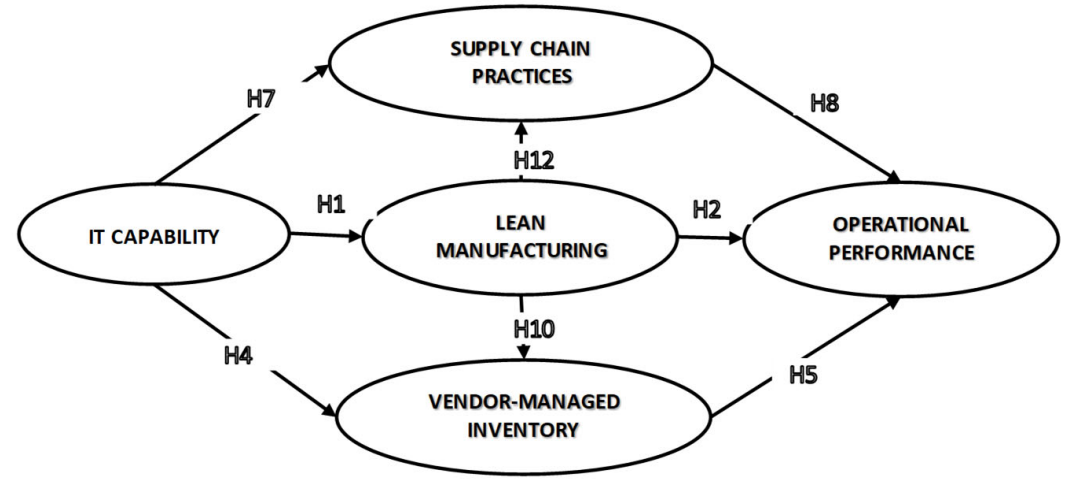

Note: Indirect hypotheses (H3, H6, H9, H11, H12, H13) are not shown.

Fig. 1. Research Model

\section{Result}

\subsection{Indicators Validity and Reliability}

The convergent validity, denoted by factor loading value, test results are demonstrated in Table 1 . When the outer loading value is more significant than 0.50 , the indicator is considered valid for convergent validity. As shown, all factor loading values are greater than 0.50 , which means that all indicators of each variable are considered valid.

Table 1

Variable, Indicator and Factor Loading Value

\begin{tabular}{|c|c|c|c|}
\hline Variable & Item & Item Statement & Factor Loading \\
\hline \multirow{4}{*}{ IT capability } & IC1 & IT capability support the company business processes & 0.666 \\
\hline & IC2 & Information systems are integrated to enable rapid change & 0.766 \\
\hline & IC3 & Information systems are compatible with company requirement & 0.769 \\
\hline & IC4 & The information system is highly reliable & 0.688 \\
\hline \multirow{8}{*}{ Lean Production } & LM1 & Multifunctional participation in the business process & 0.824 \\
\hline & LM2 & Continuous improvement & 0.744 \\
\hline & LM3 & Implementation of $5 \mathrm{~S}$ & 0.840 \\
\hline & LM4 & Total productive maintenance & 0.786 \\
\hline & LM5 & Adoption of Kanban systems & 0.798 \\
\hline & LM6 & Adoption of just in time management & 0.754 \\
\hline & LM7 & Stock reduction & 0.715 \\
\hline & LM8 & Kaizen circles implementation & 0.745 \\
\hline \multirow{5}{*}{ Firm performance } & OP1 & Reduced cost & 0.863 \\
\hline & $\mathrm{OP} 2$ & Increased productivity & 0.909 \\
\hline & OP3 & Increased new product development & 0.895 \\
\hline & OP4 & Process flexibility practices & 0.828 \\
\hline & OP5 & Responsive delivery & 0.877 \\
\hline \multirow{5}{*}{ Supply chain practices } & SCP1 & Strategic supplier partnership & 0.846 \\
\hline & $\mathrm{SCP} 2$ & Customer relationship management & 0.721 \\
\hline & SCP3 & Information sharing between partners & 0.845 \\
\hline & SCP4 & Quality information sharing & 0.820 \\
\hline & SCP5 & Postponement of differentiation & 0.838 \\
\hline \multirow{7}{*}{ Vendor-managed inventory } & VMI1 & Mutual agreement with the supplier & 0.565 \\
\hline & VMI2 & Collaborative forecasting & 0.828 \\
\hline & VMI3 & Establishment of a quality relationship & 0.810 \\
\hline & VMI4 & Agreed vendor performance measurement & 0.852 \\
\hline & VMI5 & Cost benefits for both partners & 0.833 \\
\hline & VMI6 & Service benefits from the vendor & 0.789 \\
\hline & VMI7 & Inventory management benefits & 0.852 \\
\hline
\end{tabular}


Indicator validity is also assessed for the discriminant validity using the Fornel-Larcker criterion, as shown in Table 2 . FornerLarcker criterion compares the square root of average extracted variance (AVE) value of each variable, value in the diagonal of Table 2, with the correlation between the corresponding variable with others. As long as the square root of the AVE is greater than the correlation of the corresponding variable with other variables, then the indicators are considered valid for discriminant validity. Table 2 shows that all values in the diagonal are greater than other values in the same column. This result means that all indicators are valid for discriminant validity.

Table 2

Forner-Larcker Criterion

\begin{tabular}{|c|c|c|c|c|c|}
\hline Construct & IT cap. & $\begin{array}{l}\text { Lean } \\
\text { manuf. }\end{array}$ & $\begin{array}{c}\text { Oper. } \\
\text { perform. }\end{array}$ & Sup. ch. practices & $\begin{array}{c}\text { Vend.-man. } \\
\text { inv. }\end{array}$ \\
\hline IT capability & 0.724 & & & & \\
\hline Lean production & 0.400 & 0.777 & & & \\
\hline Firm performance & 0.355 & 0.647 & 0.875 & & \\
\hline Supply chain practices & 0.414 & 0.688 & 0.683 & 0.815 & \\
\hline Vendor-managed inventory & 0.387 & 0.475 & 0.633 & 0.495 & 0.795 \\
\hline
\end{tabular}

Further assessment is the reliability of each variable used to determine the precision and consistency of block indicators of each variable. The reliability is tested by examining Cronbach's alpha, composite reliability, and AVE values. Indicators are considered reliable when the variable has a Cronbach's Alpha, composite reliability value greater than 0.70 , AVE value greater than 0.50 .

Table 3

Cronbach's Alpha, Composite Reliability, and AVE

\begin{tabular}{lccc}
\hline Variable & $\begin{array}{c}\text { Cronbach's } \\
\text { Alpha }\end{array}$ & Composite Reliability & $\begin{array}{c}\text { Average Variance } \\
\text { Extracted (AVE) }\end{array}$ \\
\hline IT capability & 0.712 & 0.814 & 0.524 \\
Lean production & 0.906 & 0.924 & 0.603 \\
Firm performance & 0.924 & 0.942 & 0.766 \\
Supply chain practices & 0.873 & 0.908 & 0.665 \\
Vendor-managed inventory & 0.900 & 0.922 & 0.633 \\
\hline
\end{tabular}

Table 3 demonstrated that all Cronbach's Alpha and Composite reliability values exceed 0.70, and AVE values also exceed 0.50 . Hence, this result indicated that those indicators of each variable are reliable, and further analysis to examine the hypotheses can proceed. According to Table 4, most respondents (39.6 percent) work for companies in the basic and chemical industries, followed by the food and beverage sector ( 20.7 percent), textiles (19.8 percent), automotive (11.7 percent), and household ( 8.15 percent). As predicted, this composition of respondents reflects the cohort of the manufacturing industry in general. Hence, the respondents are considered representative of manufacturing companies in the region of East Java, Indonesia.

Table 4

Respondents Profile by Sector

\begin{tabular}{lcc}
\hline \multicolumn{1}{c}{ Industry } & Frequency & Percentage (\%) \\
\hline Food and beverage & 23 & 20,7 \\
Automotive & 13 & 11,7 \\
Textile & 22 & 19,8 \\
Basic and chemical & 44 & 39,6 \\
Household & 9 & 8,1 \\
TOTAL & $\mathbf{1 1 1}$ & $\mathbf{1 0 0}$ \\
\hline
\end{tabular}

\subsection{Hypotheses Testing}

The significance level for hypothesis testing was set to $95 \%$, which corresponds to a critical t-statistic value of 1.96 . When the t-statistic value exceeds 1.96 , or the p-value is less than $0.05(5 \%)$, the results support the study hypothesis.

The outcome of the hypothesis testing is shown in Table 5. All of the t statistic values are greater than 1.96 excepts for hypothesis H9. IT capability directly affects lean production, Vendor-managed inventory, and supply chain practices (H1, H4, $\mathrm{H} 7)$. Moreover, lean production, vendor-managed inventory, and supply chain practice influence firm performance (H2, H5, H8). Lean production affects vendor-managed inventory and supply chain practices (H10, H12). On the other hand, the indirect relationship, as shown in Table 5, IT capability indirectly improves firm performance through lean production and vendor-managed inventory $(\mathrm{H} 3, \mathrm{H} 6, \mathrm{H} 11, \mathrm{H} 13)$. One hypothesis that is not supported is $\mathrm{H} 9$ that IT capability did not indirectly 
affect firm performance through supply chain practices. The result of the analysis from SmartPLS software is presented in Fig. 2.

Table 5

Hypothesis Test result (Direct and Indirect Effect)

\begin{tabular}{lcc}
\hline Hypothesis & $\begin{array}{c}\text { Path Statistics } \\
\text { Coefficient }\end{array}$ & 0.400 \\
\hline IT capability $\rightarrow$ Lean production (H1) & 6.000 \\
Lean production $\rightarrow$ Firm performance (H2) & 2.375 & 0.248 \\
IT capability $\rightarrow$ Lean production $\rightarrow$ Firm performance (H3) & 0.109 & 0.234 \\
IT capability $\rightarrow$ Vendor-managed inventory (H4) & 2.330 & 0.347 \\
Vendor-managed inventory $\rightarrow$ Firm performance (H5) & 3.676 \\
IT Capability $\rightarrow$ Vendor-Managed Inventory $\rightarrow$ Firm Performance (H6) & 0.084 \\
IT capability $\rightarrow$ Supply Chain Practices (H7) & 0.166 \\
Supply chain practices $\rightarrow$ Firm performance (H8) & 0.341 \\
IT capability $\rightarrow$ Supply chain practices $\rightarrow$ Firm performance (H9) & 2.291 \\
Lean production $\rightarrow$ Vendor-managed inventory (H10) & 3.300 \\
IT capability $\rightarrow$ Lean production $\rightarrow$ Vendor-managed inventory $\rightarrow$ Firm performance (H11) & 1.911 \\
Lean production $\rightarrow$ Supply chain practices (H12) & 4.024 & 0.069 \\
IT capability $\rightarrow$ Lean production $\rightarrow$ Supply chain practices $\rightarrow$ Firm performance (H13) & 0.382 \\
\hline
\end{tabular}

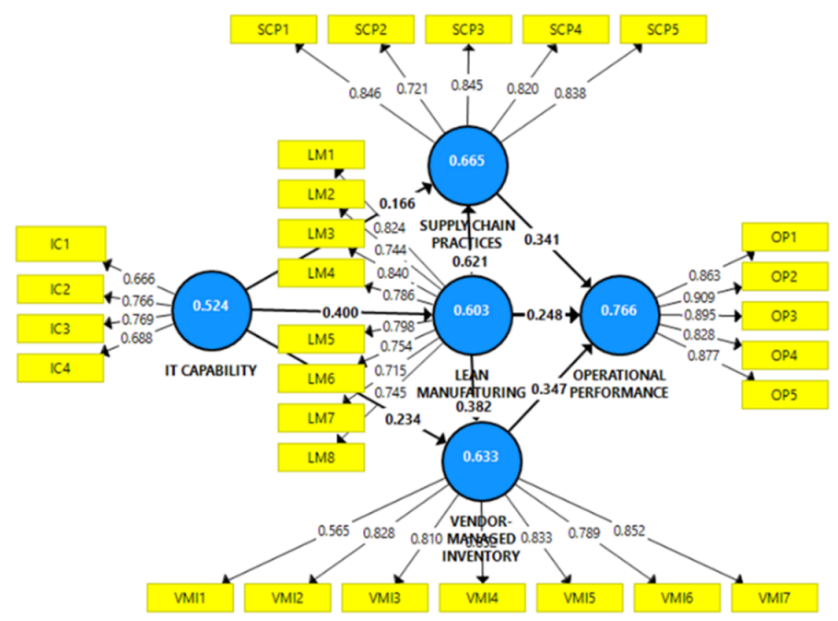

Fig. 2. Research Model with the result

\section{Discussion}

The primary objective of this study is to investigate the central role of IT capability in improving firm performance through lean production, vendor-managed inventory, and supply chain practices. The analysis results have been demonstrated in Table 5 and Figure 3. The first hypothesis, H1, states that IT capability affects lean production. This study supports the hypothesis, which aligns with previous research by Moyano-Fuentes et al. (2012). This finding extends the acceptance of a previous study on the manufacturing company in East Java, Indonesia. IT capability, defined in terms of support of the business processes, integrated across all functions, compatibility with company requirement, and high reliability, enables lean production in multifunctional participation in the process, continuous improvement, and just in time management and stock reduction. The second hypothesis, H2, lean production improves firm performance, is supported by this study. The findings of this study corroborate prior research demonstrating that implementing lean production systems within a business can increase firm performance (Fullerton \&Wempe, 2011; Hofer \&amp; Eroglu, 2012; Sánchez \&amp; Pérez, 2011). Implementing 5S is one of the indicators of lean production. The application of $5 \mathrm{~S}$ improves the performance of the manufacturing process, which results in lower production costs, shorter cycle times, and a faster response to customer requests. Lean production enables the company to reduce production cost, cope with demand fluctuations, deliver customer orders on time, and improve firm performance. Since the previous two direct relationships are supported, this finding implies that IT capability indirectly affects firm performance $(\mathrm{H} 3)$. The fourth hypothesis (H4), IT capability influences vendor-managed inventory, was supported in this research. This finding aligns with research by Marinagi et al. (2014) and Dasaklis and Casino (2019). A vendor-managed inventory practice requires an integrated information system to establish close communication and information sharing between both parties in real-time information sharing, particularly regarding the inventory system and policy of the manufacturing company. This requirement could be realized utilizing the information technology capability of the company. Moreover, the fifth hypothesis (H5) that vendor-managed inventory enhances firm performance. Vendor-managed inventory authorizes the vendor to self-manage the entire or partial raw material and components requirement of the manufacturing company. Vendor-managed inventory partnership enables manufacturing companies to access inventory data by obtaining 
information from suppliers. This information enables manufacturers to access inventory data and notify trading partners of the urgent need for raw materials, which suppliers can meet on time. Vendor-managed inventory eliminates the need for the business to maintain inventory as the vendor manages it. This result corroborates previous research indicating that implementing a vendor-managed inventory system in a business can boost firm performance (Cai \&Yang, 2014). The vendor's warehouse would supply any raw material requirements necessary to meet the manufacturing production schedule, thus lowering overall inventory costs. This assistance would help the organization by lowering manufacturing costs associated with material storage. As a result, the organization can outperform the competition on the expense or price dimension. This collaboration requires a reliable information technology capability to establish a seamless integration in the inventory management system. The sixth hypothesis (H6) stated that IT capability indirectly affects firm performance through vendormanaged inventory. This research proposed this hypothesis based on the two direct relationships, and the results supported it. IT capability integrates the system and enables the implementation of vendor-managed inventory in provisioning the raw material based on demand. In the end, it allows the lower production cost and on-time delivery for better firm performance during the current pandemic environment.

Furthermore, the seventh hypothesis (H7), IT capability affects supply chain practices. The result supported this argument and is consistent with previous findings by Marinagi et al. (2014). Supply chain practices virtually integrate all partners in the supply chain, particularly distributors and retailers in this context. The collaboration among all partners is only possible once they are connected in real-time in terms of demands, supply, and logistics network performance. IT capability provides a system covering all partners in the supply chain, and all parties are connected in a real-time environment. Similarly, the eighth hypothesis (H8) that supply chain practices affect firm performance, as expected, was supported. These findings corroborate prior studies demonstrating that a company's supply chain practices enhance firm performance (Abdallah et al., 2016). This finding is critical for manufacturing company managers to consider as they strive for improved firm performance, particularly during the Covid-19 pandemic. A stronger relationship between supply chain participants speeds up the execution of a business process, resulting in improved firm performance. By implementing supply chain policies, a business is obligated to consult with consumers to decide product requirements. Once the product requirements are established, the company can create a new product that meets the needs and demands of customers, especially during this pandemic. This finding indicates that implementing supply chain practices and vendor-managed inventory significantly affects lean production's firm performance. On the contrary, the ninth hypothesis (H9) was not significantly supported in this research. Even though the two direct hypotheses supporting this indirect hypothesis were supported, this hypothesis is not in line with the direct relationship. Hence, IT capability did not indirectly improve firm performance through supply chain practices. Meanwhile, H10 stating that lean production affects vendor-managed inventory was accepted. The finding is that lean production facilitates the introduction of vendor-managed inventory. Lean production promotes cooperation between management and suppliers in the form of vendor-managed inventory. The findings corroborate prior research indicating that implementing a vendor-managed inventory system will boost firm performance (Cai \& Yang, 2014; Guimarães et al., 2013). Establishing a dedicated team to resolve issues allows the organization to predict potential issues and helps the team to work with the supplier. This partnership enables the business to adapt to changes in consumer demand shifting. Vendor-managed inventory implies that the vendor is authorized to manage its inventory for raw material under a mutual agreement. This agreement could assist the manufacturing company in practicing a lean production process, particularly in minimizing the inventory cost and reducing the lead time. This cooperation, in the end, will improve the organizational performance such as delivery time and customer relationship.

The other result indicated that H11 was also supported. IT capability indirectly improves firm performance through lean production and vendor-managed inventory. Moreover, H12 stating that supply chain practices directly influence firm performance was supported. This finding corroborates prior studies demonstrating that a company's supply chain practices enhance firm performance (Abdallah et al., 2016). By implementing supply chain policies, a business is obligated to consult with consumers to decide product requirements. Once the product requirements are established, the company can create a new product that meets the needs and demands of customers, especially during this pandemic. The last hypothesis, H13, IT capability indirectly improves firm performance through lean production and supply chain practices is supported. This study supported this hypothesis. This finding could be interpreted as follows: Once the company has a compatible and reliable IT capability that could integrate with real-time information from internal functions, and the essential internal information is accessible by the external partner such as supplier, distributors, and retailers, the supply chain partners can coordinate together with the same goal to fulfill the customer orders right time, right product, good quality, and price. In the end, the firm performance will be improving. Given the current pandemic environment, using compatible and reliable information technology emerges as one of the solutions to support the implementation of lean production, vendor-managed inventory, and supply chain practices to pursue superior and sustainable firm performance. It is not easy to implement all these practices, but this study proves that the company needs to cope with the current pandemic.

In summary, this study highlighted how a manufacturing company could recover its firm performance in the era of the COVID-19 pandemic. The manufacturing company needs to use compatible and reliable information technology to establish lean production processes, supply chain practices, and vendor-managed inventory to enhance firm performance during the pandemic situation. This study has demonstrated the central role of IT capability in improving firm performance. A manufacturing company could manage and control all its activities by adopting this model from raw material and component supply, the internal business process by adopting lean production, and supply chain network collaboration. This collaboration will guarantee a smooth business process along with the supply chain network. An excellent overall business process will 
provide a competitive advantage for the company. An excellent business process supported by the best information technology will provide a much higher benefit to the firm performance of the manufacturing company.

\section{Conclusion}

This study aimed to determine the central role of IT capability in improving firm performance through lean production, vendor-managed inventory, and supply chain practices. The model of the research proposed thirteen (13) hypotheses. The result indicated that 12 of 13 hypotheses were supported, and one hypothesis was rejected (H9). The IT capability directly influences lean production, vendor-managed inventory, and supply chain practices. Furthermore, lean production, vendormanaged inventory, and supply chain practice directly affect firm performance. Moreover, IT capability indirectly improves firm performance through lean production, vendor-managed inventory. On the contrary, IT capability did not indirectly improve firm performance through supply chain practices. The research findings demonstrated that IT capability plays a central role in improving firm performance. IT capability provides multiple effects on firm performance, either direct effect or indirect effect. Hence, this study could provide deep insight for industrial professionals on improving and sustaining firm performance given the current endless pandemics. However, this study has the limitation in terms of the limited population surveyed and constructs involved. Future research is advised to consider a broader population and variables such as customer relationship and supply chain risk management to involve broader stakeholder and business functions.

\section{References}

Abdallah, A.B., Anh, P.C., \& Matsui, Y. (2016). Investigating the effects of managerial and technological innovations on firm performance and customer satisfaction of manufacturing companies. International Journal of Business Innovation and Research, 10(2/3), 153-183, DOI: 10.1504/IJBIR.2016.074824

Abreu-Ledón, R., Luján-García, D.E., Garrido-Vega, P. and Escobar-Pérez, B. (2018). A meta-analytic study of the impact of lean production on business performance. International Journal of Production Economics, 200, 83-102, doi.org/10.1016/j.ijpe.2018.03.015

Al-Shboul, M.A.R., Barber, K.D., Garza-Reyes, J.A., Kumar, V., \& Abdi, M.R. (2017). The effect of supply chain management practices on supply chain and manufacturing firms' performance. Journal of Manufacturing Technology Management, 28(5), 577-609, DOI 10.1108/JMTM-11-2016-0154

Anand, N. \& Grover, N. (2015). Measuring retail supply chain performance: Theoretical model using key performance indicators (KPIs). Benchmarking: An International Journal, 22(1), 135-166, https://doi.org/10.1108/BIJ-05-2012-0034

Blome, C., Paulraj, A. and Schuetz, K. (2014). Supply chain collaboration and sustainability: a profile deviation analysis. International Journal of Operations \& Production Management, 34(5), 639-663, https://doi.org/10.1108/IJOPM-11-2012-0515

Cai, J., Hu, X., Tadikamalla, P., and Jennifer, S. (2017). Flexible contract design for VMI supply chain with service-sensitive demand: Revenue-sharing and supplier subsidy. European Journal of Operational Research, 261(1), 143-153, doi.org/10.1016/j.ejor.2017.01.043

Cai, J., Zhong, M., Shang, J., \& Huang, W. (2017). Coordinating VMI supply chain under yield uncertainty: Option contract, subsidy contract, and replenishment tactic. International Journal of Production Economics, 185, 196-210, doi.org/10.1016/j.ijpe.2016.12.032

Cai, S., \& Yang, Z. (2014). On the relationship between business environment and competitive priorities: The role of performance frontiers. International Journal of Production Economics, 151, 131-145. https://doi.org/, https://doi.org/10.1016/j.ijpe.2014.02.005

Chen, J.C., Cheng, C.-H., \& Huang, P.B. (2013). Supply chain management with lean production and RFID application: A case study. Expert Systems with Applications, 40, 3389-3397,doi.org/10.1016/j.eswa.2012.12.047

Claassen, M.J.T., van Weele, A.J. \& van Raaij, E.M. (2008). Performance outcomes and success factors of vendor managed inventory (VMI). Supply Chain Management, 13(6), 406-414. https://doi.org/10.1108/13598540810905660.

Dasaklis, T., \& Casino, F. (2019). Improving Vendor-managed Inventory Strategy Based on Internet of Things (IoT) Applications and Blockchain Technologies. ICBC 2019 - IEEE International Conference on Blockchain and Cryptocurrency, 50-55. https://doi.org/10.1109/BLOC.2019.8751478

Dora, M.K., Kumar, M., Goubergen, D. Van, Molnar, A., \& Gellynck, X. (2013). Firm performance and critical success factors of lean Manufacturing in European food processing SMEs. Journal of Trends in Food Science \& Technology, 31(2), 156-164, doi.org/10.1016/j.tifs.2013.03.002

Escuín, D., Polo, L., and Ciprés, D. (2017). On the comparison of inventory replenishment policies with time-varying stochastic demand for the paper industry. Journal of Computational and Applied Mathematics, 309, 424-434, doi.org/10.1016/j.cam.2016.03.027

Flynn, B.B., Huo, B., \& Zhao, X. (2010). The impact of supply chain integration on performance: A contingency and configuration approach. Journal of Operations Management, 28(1), 58-71. https://doi.org/10.1016/j.jom.2009.06.001

Guimarães, C.M., Carvalho, J.C. de, \& Maia, A. (2013). Vendor-managed inventory (VMI): Evidence from lean deployment in healthcare. Strategic Outsourcing an International Journal, 1(6).

Hair, J.F., Risher, J.J., Sarstedt, M. and Ringle, C.M. (2019). When to use and how to report the results of PLS-SEM. European Business Review, 31(1), 2-24. https://doi.org/10.1108/EBR-11-2018-0203

Hao, Z., Liu, C., \& Goh, M. (2021). Determining the effects of lean production and servitization of manufacturing on sustainable performance. Sustainable Production and Consumption, 25, 374-389, doi.org/10.1016/j.spc.2020.11.018

Hardcopf, R., Liu, G.J., \& Shah, R. (2021). Lean production and firm performance: The influence of organizational culture. International Journal of Production Economics, 235, 108060, doi.org/10.1016/j.ijpe.2021.108060 
Jabbour, C.J.C., De Sousa Jabbour, A.B.L., Govindan, K., Teixeira, A.A., \& De Souza Freitas, W.R. (2013). Environmental management and firm performance in automotive companies in Brazil: The role of human resource management and lean manufacturing. Journal of Cleaner Production, 47, 129-140. https://doi.org/10.1016/j.jclepro.2012.07.010

De Sousa Jabbour, A.B.L., Jabbour, C.J.C., Hingley, M., Vilalta-Perdomo, E.L., Ramsden, G. and Twigg, D. (2020). Sustainability of supply chains in the wake of the coronavirus (COVID-19/SARS-CoV-2) pandemic: lessons and trends. Modern Supply Chain Research and Applications, 2(3), 117-122. https://doi.org/10.1108/MSCRA-05-2020-0011

Kamjdoug, J.R.K., Tewamba, H.J.N., \& Wamba, S.F. (2019). IT capabilities, firm performance and the mediating role of ISRM: A case study from a developing country. Business Process Management Journal, 25(3), 476-494. https://doi.org/10.1108/BPMJ$\underline{11-2017-0297}$

Khalil, M.K., Khalil, R. \& Khan, S.N. (2019). A study on the effect of supply chain management practices on organizational performance with the mediating role of innovation in SMEs. Uncertain Supply Chain Management 7(2) 179-190, doi: $10.5267 /$ j.uscm.2018.10.007

Li, S., Nathan, R., \& Rao, S. (2016). The impact of supply chain management practices on competitive advantage and organizational performance. Omega, 2(34), 107-124

Liu, H., Huang, Q., Wei, S., \& Huang, L. (2015). The impacts of IT capability on internet-enabled supply and demand process integration and firm performance in manufacturing and services. International Journal of Logistics Management, 26(1), 172194. https://doi.org/10.1108/IJLM-11-2013-0132

Manzouri, M., Ab-Rahman, M.N., Zain, C.R.C.M., \& Jamsari, EA (2014). Increasing production and eliminating waste through lean tools and techniques for halal food companies. Journal of Sustainability, 12(6), 9179-9204, doi:10.3390/su6129179

Marinagi, C., Trivellas, P., \& Sakas, D. P. (2014). The Impact of Information Technology on the Development of Supply Chain Competitive Advantage. Procedia - Social and Behavioral Sciences, 147, 586-591. https://doi.org/10.1016/j.sbspro.2014.07.161

Mateen, A., and Chatterjee, A.K. (2015). Vendor managed inventory for single-vendor multi-retailer supply chains. Decision Support Systems, 70, 31-41, doi.org/10.1016/j.dss.2014.12.002

Moyano-Fuentes, J., Martínez-Jurado, P. J., Maqueira-Marín, J. M., \& Bruque-Cámara, S. (2012). Impact of use of information technology on lean production adoption: Evidence from the automotive industry. International Journal of Technology Management, 57(1/2/3), 132-148. https://doi.org/10.1504/IJTM.2012.043955

Omar, R., Ramayah, T., Lo, M., Sang, T.Y., \& Siron, R. (2010). Information sharing, information quality, and usage of information technology (IT) tools in Malaysian organizations. African Journal of Business Management, 4(12), 2486-2499. https://doi.org/10.5897/AJBM.9000352

Prajogo, D., Toy, J., Bhattacharya, A., Oke, A., \& Cheng, T.C.E. (2018). The relationships between information management, process management and firm performance: Internal and external contexts. International Journal of Production Economics, 199(March), 95-103. https://doi.org/10.1016/j.ijpe.2018.02.019

Sainathan, A., \& Groenevelt, H. (2019). Vendor managed inventory contracts - coordinating the supply chain while looking from the vendor's perspective. European Journal of Operational Research, 272, 249-260, doi.org/10.1016/j.ejor.2018.06.028

Siagian, H., Jade, K., \& Tarigan, Z.J.H. (2020). The role of affective leadership in improving firm performance through the integrated internal system and external integration FMCG Industry. International Journal of Data and Network Science, 4 (4) 365-372, doi: $10.5267 /$ j.ijdns.2020.9.002.

Sarkis, J. (2021). Supply chain sustainability: Learning from the COVID-19 pandemic. International Journal of Operations \& Production Management, 41(1), 63-73, DOI 10.1108/IJOPM-08-2020-0568

Suryanto, T. \& Mukhsin, M. (2020). Mediation of supply chain integration on the relationship between market orientation with company performance. Uncertain Supply Chain Management, 8(4) 739-744, doi: 10.5267/j.uscm.2020.7.006

Tarigan, Z.J.H. (2018). The impact of organizational commitment to the process and product innovation in improving firm performance. International Journal of Business and Society, 19(2), 335-346

Tarigan, Z.J.H., Jiputra, J.A., \& Siagian, H. (2021a). The effect of supply chain practices on retailer performance with information technology as moderating variable. International Journal of Data and Network Science, 5(1), 47-54, DOI: $10.5267 /$ j.ijdns.2020.11.003

Tarigan, Z.J.H., Mochtar, J., Basana, S.R. \& Siagian, H. (2021b). The effect of competency management on organizational performance through supply chain integration and quality. Uncertain Supply Chain Management, 9(2) 283-294, doi: 10.5267/j.uscm.2021.3.004

Tarigan, Z.J.H. \& Siagian, H. (2021). The effects of strategic planning, purchasing strategy and strategic partnership on firm performance. Uncertain Supply Chain Management, 9(2), DOI: 10.5267/j.uscm.2021.2.006

Tarigan, Z.J.H., Siagian, H., \& Bua, R.R. (2019). The impact of information system implementation to the integrated system for increasing the supply chain performance of manufacturing companies. IOP Conference Series: Material Science and Engineering, 473, 012050, doi:10.1088/1757-899X/473/1/012050

Vanichchincai. (2019). The effect of lean manufacturing on supply chain relationship and performance. Sustainability, 11 (20), 5751, doi.org/10.3390/su11205751

Zhang, X., Donk, D.P.V., \& Vaart, T. V.D. (2016). The different impacts of inter-organizational and intra-organizational ICT on supply chain performance. International Journal of Operations and Production Management, 36(7), 803-824. https://doi.org/10.1108/IJOPM-11-2014-0516

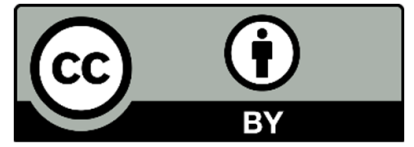

(C) 2021 by the authors; licensee Growing Science, Canada. This is an open access article distributed under the terms and conditions of the Creative Commons Attribution (CCBY) license (http://creativecommons.org/licenses/by/4.0/). 